\title{
IDENTIFIKASI TUMBUHAN EPIFIT BERDASARKAN CIRI MORFOLOGI DAN ANATOMI BATANG DI HUTAN PERHUTANI SUB BKPH KEDUNGGALAR, SONDE DAN NATAH
}

\author{
Mega Tri Suwila \\ SMP PGRI Kedunggalar \\ Email: megasilvia.trisuwila49@gmail.com \\ Diterima 3 September 2014 disetujui 2 Maret 2015
}

\begin{abstract}
The purpose of this action research is to improve the competence learning material digestive systeForests cover a lot of land vegetation, tropical rainforest is one of them, a lot of diversity tumbuahn that inhabit tropical rain forests. Perhutani forest BKPH Sub Kedunggalar, Sonde and Natah an extensive teak forests, plant species which inhabit such pembelit plants, climbing atapun adhesive (epiphytes). Identification is performed to determine the type of epiphytic plants, morphological and anatomical stem, and diversity of epiphytic plants. This qualitative study using field exploration methods, by conducting observation and identification of the morphological and anatomical stem seen from the file type transporters (xylem and phloem) in Pteridophyta and Spermatophyta in Sub BKPH Kedunggalar, Sonde and Natah. Sources of data in the form of primary data that is the result of the identification of epiphytic plants. Data collection techniques using observation and documentation, then be making the herbarium at each epiphytic plant species were found. Analysis of the data used by seebagai following stages: Data Accumulation (Collection of Data), Data Reduction (Reduction of Data), Data Display (Presentation of Data), and conclution darwing (Withdrawal Conclusion).Epiphytic plants found $3 \mathrm{Sub}$ BKPH the 5 species were divided into 2 families (Polypodiaceae and Orchidaceae) 4 genus (Drynaria, Cyclophorus, Dendrobium, and Cymbidium); Family Polypodiaceae; 2 genus is Drynaria, Cyclophorus; Drynaria species querchifdia J. Sm, Cyclophorus lanceolatus. Family Orchidaceae, which consists of 2 genera Dendrobium, Cymbidium; Dendrobium species crumenatum, bifalce Dendrobium, and Cymbidium finlaysmanum.
\end{abstract}

Keywords: Identification, Plant epiphytic, Morphology, Anatomy, learning media

\section{PENDAHULUAN}

Hutan hujan tropik merupakan salah satu vegetasi hutan yang menutupi banyak lahan. Tegakan pada hutan hujan tropis didomonasi oleh tumbuhan yang selalu hijau. Hal ini dikarenakan kondisi dari lingkungan yang lembab dan sejuk. Keanekaragaman jenis tumbuhan dan binatang yang ada di hutan hujan tropik sangat tinggi dibandingkan dengan ekosistem lainnya. Tumbuhan epifit adalah tumbuhan yang hidupnya menempel pada tumbuhan lain sebagai penopang, tidak berakar pada tanah, berukuran lebih kecil dari tumbuhan penopang atau inang, tetapi tidak merugikan terhadap tumbuhan penopang. Kebutuhan zat hara tumbuhan epifit tidak mengandalkan pada pohon inangnya, dengan demikian epifit dibedakan dari tumbuhan parasit.

Kawasan hutan milik Perhutani KPH (Kesatuan Pemangkuan Hutan) Ngawi bagian barat khususnya SUB BKPH Kedunggalar, Sonde dan Natah merupakan hutanyang memilikiberagamjenis tanaman, baik tanaman tingkat tinggi maupun tingkat rendah. Tujuan dari penelitian ini adalah untuk mengidentifikasi tumbuhan epifit berdasarkan ciri morfologi dan anatomi batang di SUB BKPH Kedunggalar, Sonde dan Natah Kabupaten Ngawi Jawa Timur yang kemudian digunakan sebagai media pembelajaran di SMA.

Tjitrosoepomo, (2007) tumbuhan epifit sebagian besar termasuk tanaman yang tingkat hidupnya rendah (lumut, 
lumut kulit, ganggang), tetapi juga terdapat paku-pakuan yang lebih senang hidup di atas tumbuh-tumbuhan lain dari pada tumbuh sendiri, Asplenium, Davallia, Hymenolepis, Drynaria, Platycerium, Cyclophorus dan Drymoglossum. Tanaman yang tingkat hidupnya tinggi terutama adalah Orchidaceae, misalnya: Dendrobium dst, jenis Ficus. Tumbuhan ini biasanya tumbuh pada tembok dan bebatuan.

Tumbuhan Epifit golongan lumut (Bryophyta), tubuh tumbuhan lumut berupa talus seperti lembaran-lembaran daun (Hepaticae). Pada tanaman lumut belum terdapat akar yang sesungguhnya, melainkan hanya rizoid-rizoid yang berbentuk benang yang kadang-kadang menyerupai akar. Alat kelamin pada tumbuhan lumut berupa Anteridium dan arkegonium. Tumbuhan lumut berkembang biak dengan spora dan vegetative dengan kuncup eram (Tjitrosoepomo, 1991).

Tumbuhan Epifit golongan pakupakuan (Pteridophyta) menyenangi daerah lembab dan teduh, dapat hidup di tanah atau menopang pada pohon lain. Tumbuhan paku memiliki bentuk yang beranekaragam, ada yang yang berdaun tunggal dan kaku, kadang-kadang menyerupai jenis anggrek. Tumbuhan paku merupakan suatu divisi yang warganya telah jelas memiliki kormus, artinya telah dengan nyata dapat dibedakan dalam tiga bagian pokok, yaitu akar, batang dan daun (Tjitrosoepomo, 1991). Tumbuhan Epifit golongan tumbuhan berbunga (Spermatophyta) antara lain famili Araceae, Bromeliaceae dan Orchidaceae, yang termasuk tumbuhan monokotil, dan tumbuhan dikotil yang meliputi Asclepiadaceae, Ericaceae, Rubiaceae dan Melastomataceae (Ewusie, 1990).

\section{METODE}

Tempat penelitian yaitu Sub BKPH Kedunggalar, Sonde dan Natah. Temuan berbagai jenis tumbuhan epifit akan diidentifikasi berdasarkan ciri morfologi dan anatomi batang dilihat dari tipe berkas pengangkut (xylem dan floem) di laboratorium Prodi Pendidikan Biologi
IKIP PGRI Madiun. Waktu pelaksanakan penelitian selama 3 bulan dimulai dari bulan Februari sampai dengan bulan April 2014.

Metode penelitian menggunakan eksplorasi dan data dianalisis menggunakan metode deskriptif kualitatif. Teknik pengumpulan data dilakukan dengan tahapan 1) Orientasi dan penjelajahan ke tiga lokasi. 2) Pengumpulan tumbuhan epifit dengan mendatangi setiap Sub BKPH. 3) Mencatat tumbuhan epifit yang ditemukan dalam setiap lokasi Sub BKPH dicatat data lapangan, didokumentasikan, dan diambil contoh koleksi untuk dibuat herbarium. 5) Spesimen yang telah diambil diberi etiket gantung berupa nomor koleksi dan dicatat data lapangan berdasarkan ciri morfologinya seperti habitat, warna, dan bentuk daun. 6) Studi pustaka untuk mengidentifikasi jenis tanaman epifit yang ditemukan dengan diamati ciri morfologi dan diamati anatomi batang menggunakan mikroskop, kemudian diidentifikasi dengan menggunakan kunci determinasi. 7) Membuat herbarium dari masing-masing koleksi yang telah ditemukan pada masingmasing lokasi atau Sub BKPH.

\section{Tumbuhan Epifit Golongan Paku- pakuan (Pteridophyta)}

Berdasarkan hasil eksplorasi pada seluruh Sub BKPH Kedunggalar, Sonde dan Natah, terdapat 6 tumbuhan epifit golongan Pteridophyta yang terdiri dari 2 spesies. Berdasarkan hasil penelitian dari Sub BKPH Kedunggalar, Sonde dan Natah ditemukan spesies tumbuhan epifit paku-pakuan yang sama. Hal ini dikarenakan pohon inang yang dijadikan penopang hidup tumbuhan epifit golongan Pteridophyta merupakan pohon yang memiliki usia tua, dalam hal ini pada tiga Sub BKPH tumbuhan tua yang dijadikan penopang adalah pohon jati dan trembesi. Setelah dilakukan identifikasi ditemukan 2 spesies tumbuhan epifit Pteridophyta yang terdiri atas 1 kelas, 1 ordo, 1 famili, dan 2 genus. 
Tabel 1. Tabel Hasil Eksplorasi di Lapangan Pada Tiga Sub BKPH

\begin{tabular}{ccccc}
\hline No & No Koleksi & Nama Spesies & Habitat & $\begin{array}{c}\text { Ditemukan pada } \\
\text { Sub BKPH }\end{array}$ \\
\hline 1 & M 01 & Drynaria quercifdia & Pohon Trembesi & Kedunggalar \\
2 & M 02 & Cyclophorus lanceolatus & Pohon Mangga & Kedunggalar \\
3 & M 01 & Drynaria quercifdia & Pohon Jati & Sonde \\
4 & M 02 & Cyclophorus lanceolatus & Pohon Jati & Sonde \\
5 & M 01 & Drynaria quercifdia & Pohon Jati & Natah \\
6 & M 02 & Cyclophorus lanceolatus & Pohon Sambi & Natah \\
\hline
\end{tabular}

Berdasarkan hasil eksplorasi pada seluruh Sub BKPH Kedunggalar, Sonde dan Natah, dikumpulkan total spesies tumbuhan epifit golongan Spermatophyta sebanyak total 9 tanaman yang terdiri dari 3 spesies. Hasil temuan pada tiga Sub $\mathrm{BKPH}$ adalah 9 tumbuhan yang setelah

didentifikasi ternyata dapat di masukkan dalam 3 spesies. Halini dikarenakan habitat yang dijadikan penopang tumbuhan epifit kebanyakan adalah pohon jati yang sudah berusia tua. Adapun hasil dari ekplorasi di lapangan tiap spesies tumbuhan pakupakuan epifit dapat dilihat pada tabel 2.

Tabel 2. Tabel Hasil Eksplorasi Spermatophyta

\begin{tabular}{|c|c|c|c|c|}
\hline No & No Koleksi & Nama Spesies & Habitat & $\begin{array}{c}\text { Ditemukan pada } \\
\text { Sub BKPH }\end{array}$ \\
\hline 1 & M 04 & Dendrobium crumenatum & $\begin{array}{l}\text { Pohon Trembesi } \\
\text { dan pohon Jati }\end{array}$ & Kedunggalar \\
\hline 2 & M 05 & Dendrobium bifalce & Pohon Jati & Kedunggalar \\
\hline 3 & M 06 & $\begin{array}{l}\text { Cymbidium } \\
\text { finlaysmanum }\end{array}$ & Pohon Jati & Kedunggalar \\
\hline 4 & M 04 & Dendrobium crumenatum & Pohon Jati & Sonde \\
\hline 5 & M 05 & Dendrobium bifalce & Pohon Jati & Sonde \\
\hline 6 & M 06 & $\begin{array}{l}\text { Cymbidium } \\
\text { finlaysmanum }\end{array}$ & Pohon Jati & Sonde \\
\hline 7 & M 04 & Dendrobium crumenatum & Pohon Jati & Natah \\
\hline 8 & M 05 & Dendrobium bifalce & Pohon Jati & Natah \\
\hline 9 & M 06 & $\begin{array}{l}\text { Cymbidium } \\
\text { finlaysmanum }\end{array}$ & Pohon Jati & Natah \\
\hline
\end{tabular}

Sub BKPH Kedunggalar, Sonde dan Natah ditemukan spesies tumbuhan epifit golongan Spermatophyta yang sama. Hal ini dikarenakan pohon inang yang dijadikan penopang hidup tumbuhan epifit golongan Spermatophyta merupakan pohon yang memiliki usia tua, dalam hal ini pada tiga Sub BKPH tumbuhan tua yang dijadikan penopang adalah pohon jati dan trembesi.

Berdasarkan hasil eksplorasi didapatkan koleksi tumbuhan epifit pakupakuan dari tiga Sub BKPH ditemukan 6 tumbuhan epifit golongan paku-pakuan dan setelah diidentifikasi diperoleh 2 spesies tumbuhan epifit golongan paku- pakuan. Temuan dari masing-masing Sub BKPH menunjukkan tumbuhan epifit paku-pakuan yang sama, kesamaan jenis tumbuhan epifit paku-pakuan ini dikarenakan habitat yang dijadikan penopang ini sama yaitu pohon-pohon yang berusia tua. Pohon-pohon yang dijadikan penopang atau habitat untuk tumbuhan epifit golongan paku-pakuan diantaranya adalah pohon jati, trembesi, sambi, mahoni. Pohon-pohon penopang yang paling banyak mendominasi adalah pohon jati, dimungkinkan karena kulit dari pohon jati yang memiliki tekstur serat lunak yang mudah untuk ditembus 
jenis akar dari tumbuhan epifit.

Hasil ekplorasi menunjukkan koleksi tumbuhan epifit golongan Spermatophyta dari tiga Sub BKPH telah ditemukan 9 tumbuhan epifit golongan Spermatophyta dan setelah diidentifikasi diperoleh 3 spesies tumbuhan epifit golongan Spermatophyta. Temuan dari masing-masing Sub BKPH menunjukkan Spermatophyta yang sama, kesamaan jenis tumbuhan epifit epifit golongan tumbuhan berbunga (Spermatophyta) ini dikarenakan habitat yang dijadikan penopang ini sama yaitu pohon-pohon yang berusia tua. Pohonpohon yang dijadikan penopang atau habitan untuk tumbuhan epifit golongan tumbuhan berbunga Spermatophyta diantaranya adalah pohon jati, trembesi, sambi, mahoni. Pohon-pohon penopang yang paling banyak mendominasi adalah pohon jati, dimungkinkan karena kulit dari pohon jati yang memiliki tekstur serat lunak yang mudah untuk ditembus jenis akar dari tumbuhan epifit. Proses identifikasi dalam penelitian ini, diperoleh data mengenai anatomi batang dilihat dari tipe berkas pengangkut pada 5 spesies tumbuhan yang ditemukan. Tipe berkas pengangkut ke 5 spesies tergolong dalam tipe kolateral tertutup karena tidak adanya kambium yang membatasi antara xylem dan floem; konsentris aphikribral untuk 2 spesies (Drynaria quercifdia dan Cyclophorus lanceolatus); konsentris aphivasal untuk 3 spesies (Dendrobium crumenatum, Dendrobium bifalce dan Cymbidium finlaysmanum.

\section{SIMPULAN}

bahwa:

Hasil penelitian menunjukkan

1. Jenis-jenis tumbuhan epifit golongan Pteridophyta dan Spermatophyta pada Sub BKPH Kedunggalar, Sonde dan Natah total ditemukan 5 spesies : Drynaria querchifdia J. Sm, Cyclophorus lanceolatus, Dendrobium crumenatum, Dendrobium bifalce, dan Cymbidium finlaysmanum.
2. Ciri Morfologi masing-masing spesies hampir mirip, mulai dari akar, batang dan daun, karena masih dalam satu famili. Anatomi Batang dilihat tipe berkas pengangkut xylem dan floem, ke 5 spesies tergolong dalam tipe kolateral tertutup, konsentris aphikribral dan konsetris aphivasal

3. Keanekaragaman jenis tumbuhan epifit pada tiga Sub BKPH sama. Ketiga lokasi penelitian didapatkan spesies yang sama, perbedaan yang ditunjukan pada banyak sedikitnya inang, paling banyak terdapat pada Sub BKPH Sonde karena lokasi ini dekat pemukiman warga sehingga pihak Perhutani membiarkan tumbuhan tidak ditebang sebagai pengayoman.

\section{DAFTAR PUSTAKA}

Ewusie, J. Y. 1990. Pengantar Ekologi Tropika. Bandung: ITB.

Tjitrosoepomo, Gembong. 1992. Taksonomi Tumbuhan Schizophyta, Thallophyta, Bryophyta, Pteridophyta. Yogyakarta: Gadjah Mada University Press.

Tjitrosoepomo, Gembong. 2007. Morfologi Tumbuhan. Yogyakarta: Gajah Mada University Press.

Van Stennis, C. G. G. J. 2005. Flora untuk sekolah di Indonesia. Jakarta: Pramudya Paramita. 